\title{
Imagining an (Un)productive Anthropology Through the Night
}

\author{
Vishwaveda Joshi \& Ira Famarin
}

\begin{abstract}
Through this email exchange, we have tried to engage with ourselves by considering our bodies as archives of trauma, feelings, and ideas, using the thematic of the nighttime and nightness. Nightness emerges as a counter epistemology in our rumination and it transfigures the dualisms of day and night, productive and unproductive as merging in space and time. By writing ourselves as bodies of the night, such that we belong both to the day and to the night, or perhaps neither to the day nor to the night, we use the night and nightness to process our grief; to feel grief and to escape away from it into a possibility of thinking/feeling where we exist and we don't at the same time. These emails not only suggest a counter epistemology but also the possibility of an (un)productive anthropology, one which happens within each of us around nightness - away from the day, or rather, away from the neoliberal expectation of the day.
\end{abstract}

\section{Keywords}

(un)productive anthropology; nightness; grief; body; trauma 
New Sociology: Journal of Critical Praxis

Hello Dear Friend,

As I sit staring out of my beautiful French windows of the new apartment, thinking about going back to a busier life, to our days defined by work hours, and letting the thinking sink in, I felt you, and your presence. You are thus receiving this email as I think about you and productivity and night and speculations.

As always, I am drawn to the moon, and by that extent to the nightness of the moon. What do I mean by nightness? Do I mean the quality of night... or am I referring to the time between sunset and sunrise; when the moon is made apparent? I think that nightness might mean a state in which my body feels the most joy and peace, it feels itself. I can think in the quiet of the night, the way I cannot think during the day. I can almost re-balance myself at night, and especially with so much information to process (Police Brutality, COVID-19; climate change), night has become my time for equilibrium, for processing, for grieving, its as though the nightness of the moon, and that of the night, elicits healing and processing of trauma itself. Can anything have nightness? Can we then challenge the temporality of night?

That's all for now!

Vishwaveda.

[ August 16, 2020, 00: 51 ] 


\section{Hi Dear Friend,}

It's so nice to hear from you. I figured I'll reply immediately as I have been sleeping late these days. My nights are long and quiet. It's currently 2:30am as I type this and I just made some chai tea (inspired by the chai tea that you made me last time).

You and the moon - I remembered the time that we chased the moon together! It was bright, full and round last time. Tonight, its crescent shape is pale behind the clouds. When you mentioned the processing, rebalancing and healing that happen at night, I think about how it is like the moon phases. We go through different phases at night. There are some nights that I truly enjoy my solitude and take the time to journal, read and pray but there are also some nights when everything is so heavy that I just want to sleep it off. Can nightness then be associated with escape as well? To escape from the noise, the chaos, the reality that we live in. I feel the most raw at night because I can just be - free from the pressure and expectations of the day.

My brain is frozen right now, so nighty in the meantime!

Ira

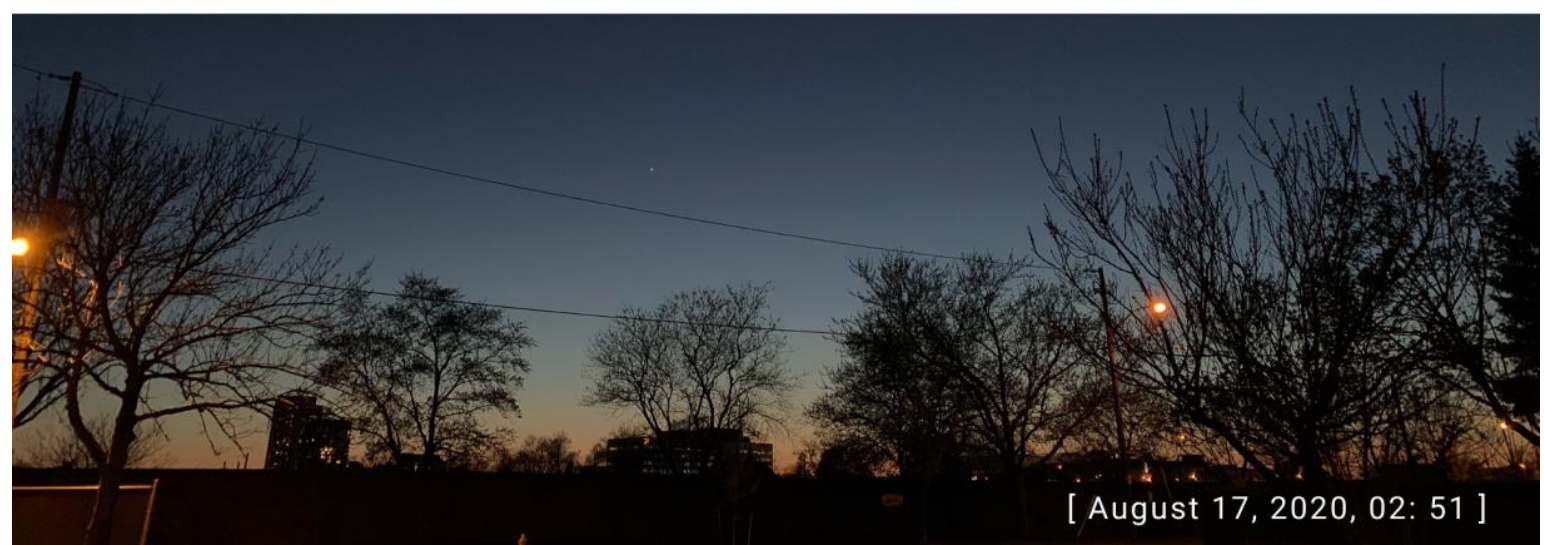




\section{Dear Friend,}

Once again, thoughts are taking shape, asserting their presence as I look at the moon through my window and attempt to sleep. I had a profound experience today at the Van Gogh Immersive Art Exhibit, and the thoughts that are wrapping me, are very much related to the profoundness of the experience. The music, the beautiful paintings that were brought to life through space and time manoeuvres, and of course the darkness, which reminded me of the night, or gave me a sense of the night, allowed me to let go and grieve freely, honestly and fully. I could not stop crying as I sat through the exhibit. Grieving about what, you might ask... grieving about the state of the world, not just because of the pandemic, but also because of the several injustices happening all around the world from Black people across the "West" being shot and killed to Six Nations demonstrators being physically harassed and jailed for peacefully protesting, grieving, because of the unprecedented violence and trauma bodies in India and Pakistan had to experience 74 years ago, memories of which reside in each Indian and Pakistani body even today and we grieve about it/through it every single day. Grieving, because this was the first time I was in downtown Toronto since March 2020,

and grieving because there is no concern of another being's life in the contemporary times, because profits, power, corporations take precedence over life. Grieving, because of the increasing surveillance of our movements, not due to COVID, but because the State is responding to our collective solidarity against neoliberal, racist values by increasing policing. I experienced all of this and yet was able to escape into the beauty of the artworks being shown and the nightness of it. I do think that I escaped as you have written in the previous email, into perhaps a possibility of a thinking/feeling that happens within us precisely during moments such as this one where you are and you are not in order to grieve and heal and to be with the world, almost escaping like the moon does every 15 days and emerging new, stronger and determined. I have been thinking of a possibility of an (un)productive anthropology that happens within each one of us, and through us in moments of darkness, around nightness, away from the day, an anthropology that considers the body as an archive of feelings, of trauma, of knowledge and draws from the bodies responses to unease, pain and opportunity in times where our bodies are all we have!!

-Vishwaveda.

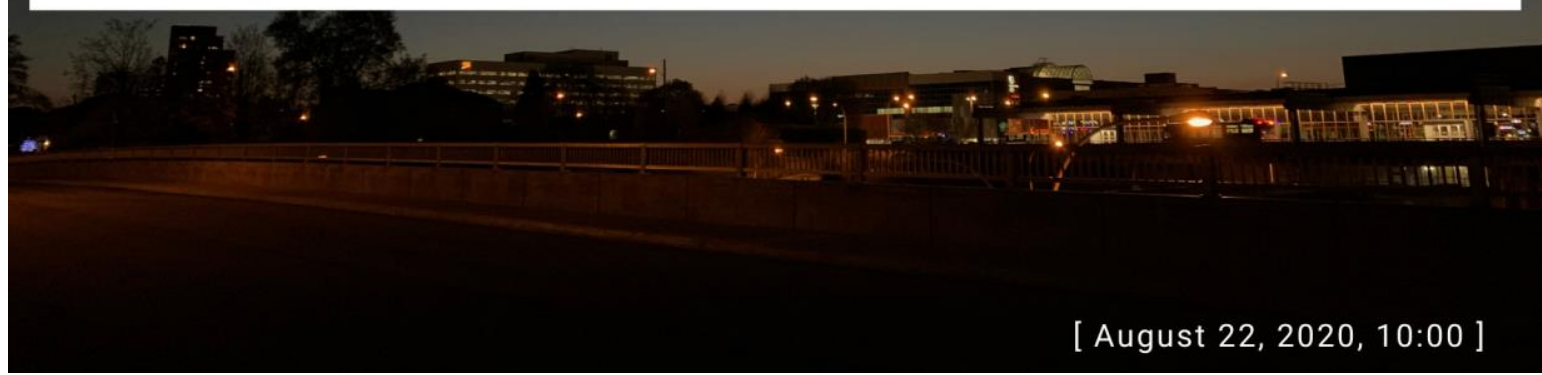




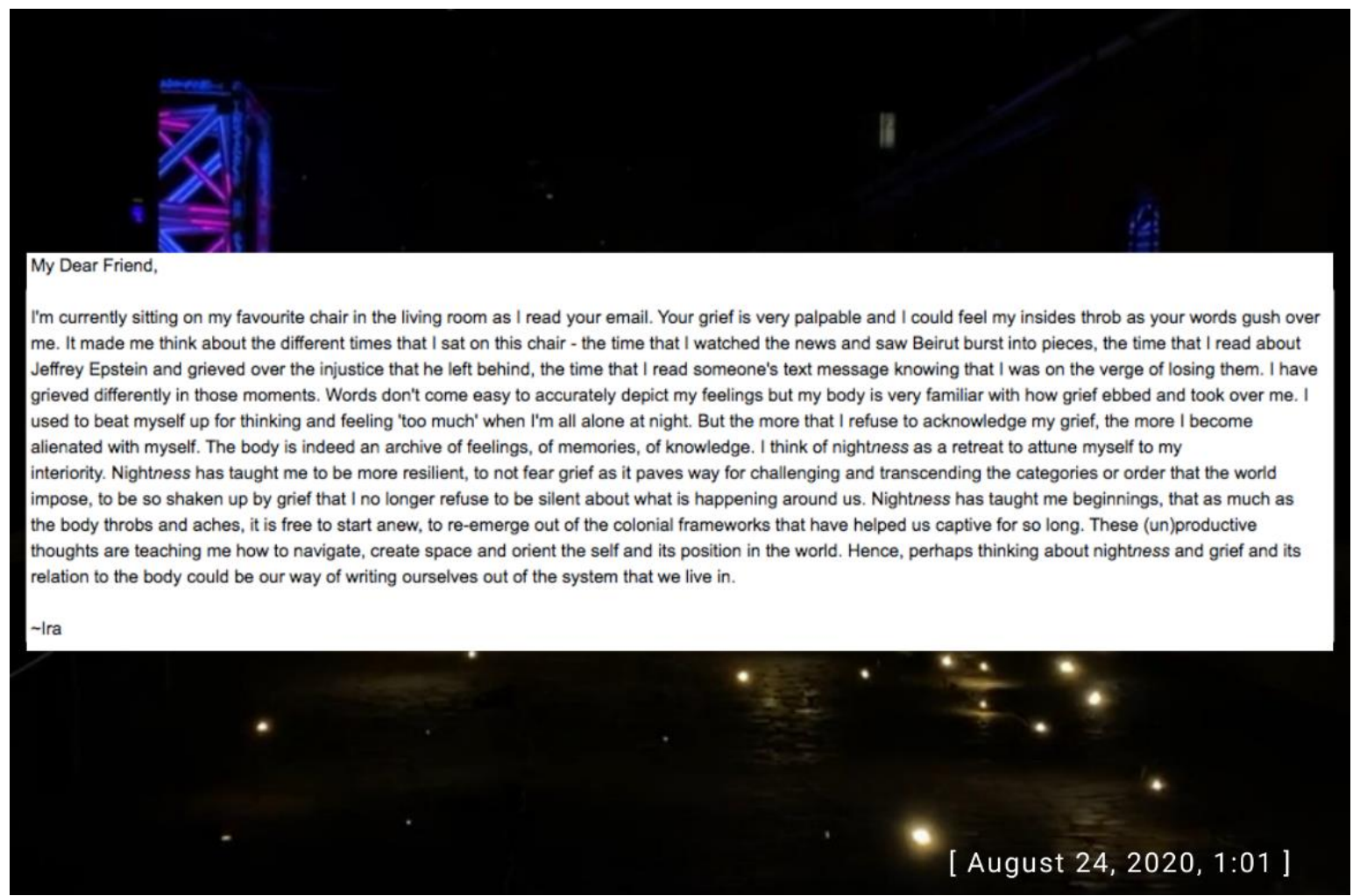


Hello Dearest friend,

I have come to love this email exchange as it has allowed me to think through the dualism of productive vs unproductive and how so much of the experience of our existence is spent in-between these dualisms. Usually, I would love to think of tensions, of in-betweenness in a very positive way, but this particular dualism causes tension that is exhausting, tiring, unrealistic. And, nightness, writing about grief (which gets pathologized and represented as unproductive) and thinking about it so purely, has really made me feel the tension of productive vs unproductive, the capitalist origins of it, and I have come to realize how I am so ready to break through these exhausting tensions.

Nightness, can become the way for me, for us, as you have written in the email, to break us out of these tensions. Nightness prompts for an anthropology that allows us to get closer to our thinking and feeling selves. It provides the thinking space that is needed for such an anthropology to emerge. Then, to sum up our email exchange, and to answer some questions that I posed at the beginning. Nightness, can be a concept that acts as a counter epistemology to the neoliberal productive expectation of the day that governs our bodies, our feelings, our thoughts. Nightness as I wrote earlier, can be a way through which we can connect to ourselves, and others - humans and beyond humans that surround us!

I am happy that we have started thinking about this, and have created an opening through these emails, to exchange thoughts and speculate. Maybe, in us being (un)productive, we are still creating-- creating thoughts, feelings, new notions to counter notions that are stifling. We are creating ways to connect with ourselves and others. We are generating after all.

I'll call you soon xxx.

Best,

Vishwaveda.

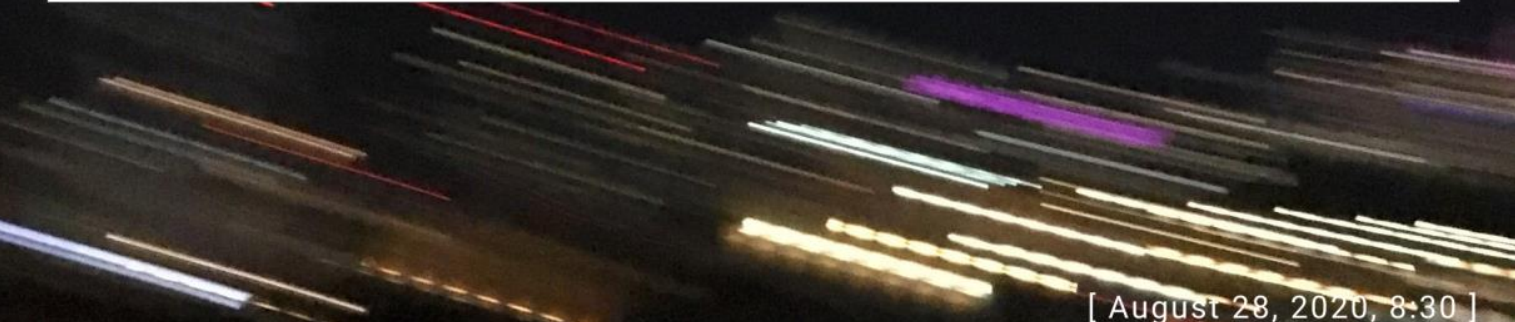




\section{Author biographies}

Vishwaveda is a graduate student of Social Anthropology and Asian Studies at York University, and a dance appreciation fellow at Upasana School of Performing Arts, Ahmedabad. Her research focuses on Kathak, an Indian Classical dance form, as a tool to understand the ongoing ways in which: 1) postcolonial bodies are colonized; and 2) to decolonize the Indian body politic, particularly by understanding the dancers' interiorities and the knowing that happens in relation to different sounds of Kathak. Vishwaveda aims to create places both within individual bodies as well as outside of them, focusing on social spaces for vulnerable, affective forms of knowing - a knowing that takes us away from categorizations and identity politics and encourages intimate interactions with humans and nonhumans. Her work challenges the view of the self-contained individual and opens up possibilities for thinking about the effects of incipient, spontaneous, and vulnerable encounters on a society with more empathy and solidarity for one another. A sensory anthropologist by practice, Vishwaveda focuses on how sensory methodologies create empathetic, experiential ways of knowing individuals' worlds.

Ira is a dancer, content curator, and arts-based researcher and community coordinator that wants to pay homage to her roots and hyphenated identity. As a Filipino who was raised in Singapore and now living in Toronto, she has always been fascinated by the varied lived experiences and narratives of different diaspora all over the world. Ira is a recent graduate of the Culture and Expression Major at York University and is currently practising artsbased research to explore her hyphenated identity and how society is implicated within larger issues of neoliberal capitalism, racism, and colonization. 